Прохорская Елена Георгиевна (Москва). Кандидат архитектуры. Главный архитектор проектов Отдела №1 Мастерской проектов генеральных планов ГАУ МО «Научно-исследовательский и проектный институт градостроительства» (129110, Москва, ул. Гиляровского, 47, стр. 3. НИиПИ градостроительства). Эл. почта: arhiv.heritage@gmail.com.

Благовидова Наталья Георгиевна (Москва). Кандидат архитектуры, доцент. Профессор кафедры «Градостроительство» ФГБОУ В0 «Московский архитектурный институт (государственная академия)» (107031, Москва, ул. Рождественка, 11. МАРХИ). Эл. почта: nablago7@yandex.ru.

Prokhorskaya Elena G. (Moscow). Candidate of Architecture, Chief Architect of Projects of Department No. 1 of the Master Plan Projects Workshop at the Research and Design Institute of Urban Planning (47 Gilyarovskogo st, building 3, Moscow, 129110. NIIPI of Urban Planning).E-mail: arhiv.heritage@gmail.com.

Blagovidova Natalia G. (Moscow). Candidate of Architecture, Associated Professor. Professor of the Urban Planning Department at the Moscow Institute of Architecture (11 Rozhdestvenka st., Moscow, 107031. MARKHI). E-mail: nablago7@yandex.ru.

๑ Прохорская Е.Г., Благовидова Н.Г., 2021. Academia. Архитектура и строительство, № 4, стр. 59-69.

\title{
Проблемы сохранения визуального восприятия объектов культурного наследия в исторических городах Московской области
}

\author{
Е.Г.Прохорская, МАРХИ, НИиПИ градостроительства, Москва \\ Н.Г.Благовидова, МАРХИ, Москва
}

В статье рассмотрены проблемы визуального восприятия объектов культурного наследия в исторических городах Московской области. На основе анализа последовательных этапов развития ряда городов в зависимости от расположения в городской среде были выделены четыре типологические группы памятников: историческое ядро, рядовая застройка регулярного периода XVIII-XIX веков, высотные доминанты, усадебные комплексы в черте города - для каждой из которых описаны характерные особенности визуального восприятия. Анализ совокупности условий природного ландшафта, рядовой застройки на основе регулярной планировки, системы высотных доминант и пространственных акцентов показал, что сложившиеся условия визуального восприятия объектов культурного наследия оказывают существенное влияние на композицию исторической планировочной структуры. Особенности и проблемы визуального восприятия объектов культурного наследия позволяют выявить комплекс мероприятий для определения границ исторического поселения, режимов его использования, ограничений, приоритетов и направления дальнейшего развития городов в современных градостроительных условиях.

Ключевые слова: культурное наследие, исторические города, Московская область, визуальное восприятие, композиционная роль, планировочная структура, высотные доминанты, архитектурно-ландшафтные комплексы.
Problems of Preserving the Visual Perception of Cultural Heritage Objects in the Historical Cities of the Moscow Region

E.G.Prokhorskaya, MARKHI, Moscow

N.G.Blagovidova, MARKHI, Moscow

The article deals with the problems of visual perception of cultural heritage objects in the historical cities of the Moscow region. Were identified four typological groups of monuments: the historical core, ordinary buildings of the regular period of the XVIII-XIX centuries, high-rise dominants, manor complexes. Those groups are based on the analysis of the successive stages of the development of cities, depending on the location in the urban environment. The characteristic features of visual perception for each group are described. It is shown that the existing conditions of visual perception of cultural heritage objects have a significant impact on the composition of the historical planning structure. They represent a set of conditions of the natural landscape, ordinary buildings based on regular planning, a system of high-rise dominants, and spatial accents.

The features and problems of visual perception of cultural heritage objects allow us to identify a set of measures to determine the boundaries of a historical settlement, modes of its use, restrictions, priorities for the further development of cities in modern urban planning.

Keywords: cultural heritage, historical cities, Moscow region, visual perception, compositional role, planning structure, highrise dominants, architectural and landscape complexes. 
Одним из актуальных вопросов последних десятилетий, связанных с продолжающимся активным строительством в Московской области, остаётся сохранение объектов культурного наследия в исторических городах. Помимо самих объектов, их архитектурного облика и планировочных элементов, важную роль в сохранении исторической среды города играют условия восприятия памятников в его планировочной структуре, которые подчёркивают значимость историко-градостроительных систем, ансамблей и панорам старинных центров городов, усадебных и монастырских комплексов [1, с. 100].

Большое значение для сохранения такой историко-градостроительной среды приобретает установление границ исторического поселения (ИП). Одной из первоочередных задач в рамках определения границ ИП является выявление территорий, вобравших в себя несколько этапов развития города и сосредоточивших в своих пределах наибольшее количество памятников архитектуры и градостроительного искусства. Кроме того, важной задачей выявления таких территорий является определение зон визуального восприятия главных исторических объектов, точек их обзора, видовых раскрытий и панорам [2, с. 12]. Визуальные связи, сложившиеся в результате последовательного развития структуры города, позволяют воспринимать объекты культурного наследия (ОКН) в окружающей среде в соответствии с первоначальным замыслом их строительства. Чтобы избежать нарушения восприятия памятников при новом строительстве, необходимо сохранение этих территорий, установления в их границах особых режимов и регламентов использования. Учёт визуального восприятия памятников при развитии исторического города играет определяющую роль в формировании его композиции и является основой сохранения историко-градостроительной среды, сложившейся на протяжении многих веков.

Древние поселения славян, заселявших территорию Подмосковья с конца IX века, располагались по берегам рек и озёр [3]. Реки служили и главными путями сообщения, торговыми маршрутами. Именно на пересечении рек и сухопутных дорог возникали первые укреплённые поселения.

Многие из таких поселений разрастались, постепенно превращаясь в древние города. В XIV-XVI века во времена существования Московского княжества, когда происходили частые набеги монголо-татар, в таких городах возникали оборонительные сооружения в виде крепостей и кремлей.

Позднее, с развитием сухопутных маршрутов и торговли такие укреплённые города получили активное развитие. В градостроительных планах XVII века чётко просматривается центр города, образованный пересечением реки и главной дороги, ведущей, как правило, из Москвы в лучевом направлении. Вдоль дороги выстраиваются ряды застройки, торговые лавки, жилые дома. Появляются высотные доминанты в виде церквей и монастырей.

В эпоху Екатерины II для каждого уездного города был составлен регулярный план с прямоугольной сеткой улиц и чётким разделением на кварталы: дворянские, купеческие, разночинные, церковнослужителей, мещанские, солдатские. В центре города зачастую находились присутственные места, торговые ряды, богадельни.

Именно такие города, благодаря значительной концентрации древних памятников архитектуры, градостроительства, истории и археологии, сегодня отнесены к числу исторических поселений [4, с. 204].

Некоторые из них представляют собой примеры малых исторических городов (Бронницы, Верея, Звенигород). В таких городах с населением до 50 тысяч жителей складывается более благоприятная ситуация для сохранения объектов культурного наследия и историко-градостроительной среды за счёт низкой этажности и низкой плотности застройки. Благодаря особенностям рельефа, компактности планировки городов и преобладанию малоэтажной застройки, в этих городах сформированы оптимальные условия для восприятия главных высотных доминант и исторической застройки, сохранение которых позволяет не потерять уникальность каждого города [5, с. 184].

Другая ситуация складывается в средних и особенно в больших исторических городах, получивших активное промышленное развитие в период XIX-XX веков, где рост численности населения повлек за собой комплексное жилищное строительство. Большие города Московской области (с населением свыше 100 тыс. человек) за счёт наиболее динамичного развития в значительной степени подвержены влиянию нового строительства на историко-культурную среду. В них зачастую наблюдается нарушение доминирующей роли главных исторических объектов, восприятия ОКН с основных видовых точек, снижение композиционного единства исторической части.

Средние города (с населением 50-100 тыс. жителей), где в последние годы особо остро чувствуются тенденции к разрастанию высокоплотной застройки, являются наиболее уязвимыми в данном отношении, однако при этом шансы на сохранение исторически сложившейся среды ещё остаются [6, с. 301].

Таким образом, определение границ исторического поселения с учётом сохранения исторических видовых раскрытий и панорам визуального восприятия основных памятников архитектуры и градостроительства играет ключевую роль в гармоничном развитии больших и средних исторических городов Московской области.

Посредством анализа последовательного формирования и развития городов (Клин, Подольск и др.) были определены основные особенности и проблемы сложившейся пространственной организации, оказывающие влияние на визуальное восприятие памятников архитектуры и истории.

Их учёт при разработке проектов границ исторического поселения, а также разделов по охране объектов культурного наследия в составе документов территориального планирования позволит установить ограничения для новой застройки, 
определить приоритеты сохранения тех или иных территорий в структуре города и векторные направления градостроительного развития [7, с. 77].

В ходе исследования объекты культурного наследия были разделены на четыре типологические группы в зависимости от расположения в городской среде и периода возникновения: 1) объекты, расположенные в историческом ядре; 2) рядовая застройка регулярного периода XVIII-XIX веков; 3) высотные доминанты церквей и храмов; 4) усадебные комплексы в черте города.

Первая группа: объекты, расположенные в историческом ядре города. К ней отнесены объекты, определяющие основу градостроительного развития поселения и формирующие его исторический центр.

Территория исторического ядра включает узловые элементы, закрепившие центр города, исторически сформировавшиеся площади, направления улиц и дорог, природноландшафтные элементы (крутые берега рек, овраги, склоны рельефа). В эту группу входят преимущественно памятники архитектуры, расположенные в месте возникновения древнего поселения, а также на главных пересечениях древних

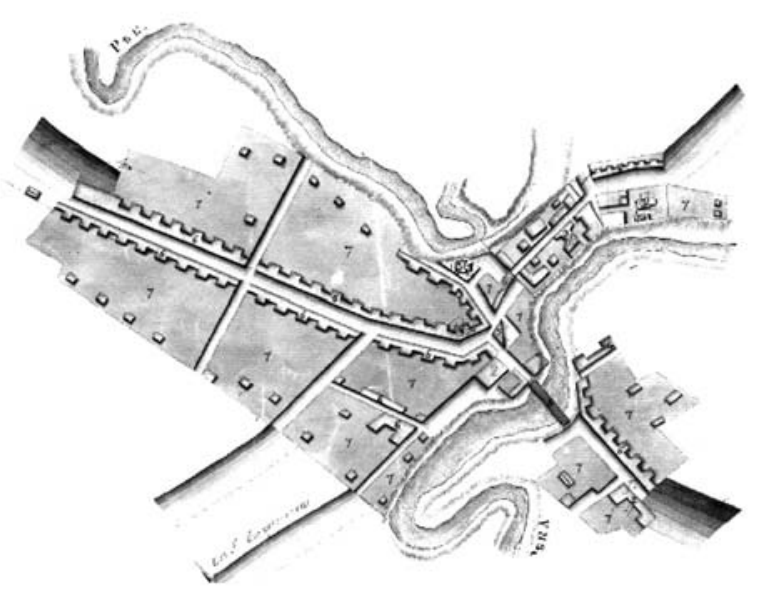

PUс. 1. План города Клина конца XVIII века (источник: РГАДА)

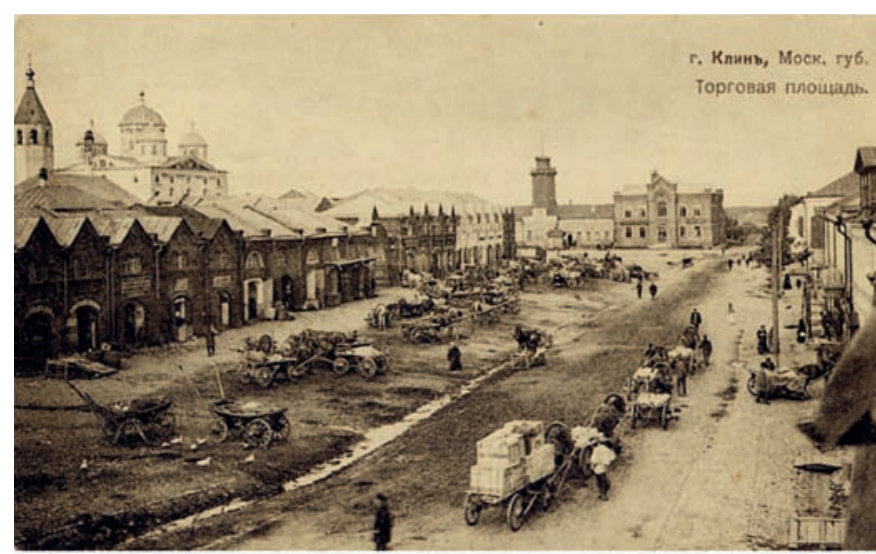

Рис. 2. Город Клин. Торговая площадь. Фото конца ХІХ века [источник: официальный сайт администрации городского округа Клин (https://klincity.ru/o-rayone/istoriya2/)] улиц, которые в значительной степени сформировали облик исторического центра города.

Так, город Клин - один из древнейших городов Подмосковья, был заложен на узком высоком перешейке петли реки Сестры, в «узкой луке», откуда и получил своё название [8, с. 118].

Здесь существовала крепость, с северо-запада и юго-востока её ограждали высокие берега реки, а с северо-востока и юго-запада - рвы и насыпные валы высотой до 5 м. Недалеко от крепости проходила транзитная дорога из Твери в Москву, вдоль которой позднее возник торг с лавками и рядами. Застройка древнего Клина была подчинена естественным формам рельефа местности [9, с. 108]. На плане города Клина конца XVIII века видны две церкви, поставленные на диагональной оси крепости и обозначившие границы древнего поселения: церковь Успения Богородицы, замыкающая пойму реки со стороны верховья, и церковь Воскресения Христова, построенная после прохождения петли [10, с. 8]. Дальнейшее развитие планировочной структуры Клина зависело от главных дорог. План города того времени представлял собой систему со сходящимися улицами из Дмитрова, Москвы, Петербурга (рис. 1).

Вдоль основных трактов вытянулись торговые лавки, постоялые дворы, винные погреба, кузницы. На правом берегу реки Сестры был выстроен деревянный путевой дворец на случай приезда высочайших императорских особ. При этом сам город вплоть до 1766 года существовал в границах крепости, где главными зданиями были воеводский дом, канцелярия, казармы и дома солдат.

Таким образом, историческое ядро Клина сформировалось излучиной реки с крутым обрывом, на вершине которого стояла церковь Воскресения Христова, основными направлениями дорог (Петербургская и Дмитровская дороги), вдоль которых выстроились ряды общественных зданий с торговыми лавками (рис. 2). Позднее на их месте по проекту архитектора С.К. Родионова были выстроены каменные торговые ряды, которые закрепили один из главных акцентов исторического ядра города и по сей день являются памятником градостроительства.

Историческое ядро древнего села Подола, ставшего в 1781 году городом Подольском, сформировалось в дорегулярный период из двух главных пространственных элементов - главной улицы села, проходившей с севера на юго-запад вдоль древней Серпуховской дороги, и церкви, возвышавшейся на высоком берегу реки Пахры, у её изгиба. На крутой горке берега Пахры первоначально располагалась деревянная церковь, взамен которой в 1728 году был возведён новый храм Воскресения Христова - первая каменная постройка. Естественный овраг, окаймляющий излучину реки Пахры, служил природным препятствием для набегов с юга и определял планировочные границы города того периода.

Трассировка древней улицы, проходившая параллельно течению реки Пахры и повторявшая конфигурацию её излу- 
чины, шла по подножию холма, который называется Красная горка. От главной улицы села Подола к северо-западу шла дорога в Москву. Древняя Серпуховская дорога была главной осью формирования поселения, вдоль которой складывалась линейная застройка. На её пересечении с излучиной реки размещались постройки городского значения - торговые лавки, кузницы, фабрики, существовала торговая площадь (рис. 3).

Судя по сохранившимся планам, историческое ядро Подольска также сложилось при сочетании природного рельефа, линейного направления исторической дороги и узлового элемента - древнего церковного сооружения.

Природные условия всегда являлись определяющим фактором в развитии городов. Именно поэтому одной из особенностей восприятия сохранившихся элементов исторического ядра является наличие видовых точек и раскрытий, сложившихся благодаря уникальным характеристикам рельефа в сочетании с основными акцентами.

Необходимость сохранения исторически сложившихся точек обзора и визуальных раскрытий, трассировок улиц и площадей в историческом ядре города является важной задачей для поддержания уникальности города и его главных композиционных особенностей.

Целостное восприятие исторического ядра и основных элементов, составляющих его пространственную структуру, лежит в основе установления границ исторического поселения и особых режимов использования его территории и оказывает первоочередное влияние на гармоничное развитие города.

Вторая группа: застройка XVIII-XIX веков вдоль главных улиц, кварталы регулярного периода.

Одним из важнейших периодов, оказавших влияние на формирование планировочной организации населённых пунктов Подмосковья и оставивших наибольшее количество объектов культурного наследия, является период середины XVIII - начала XIX века, когда по указу Екатерины II были разработаны генеральные планы губернских и уездных городов.

Сохранившаяся старая часть городов в пределах регулярного «Екатерининского» плана наглядно иллюстрирует градостроительные принципы России эпохи классицизма, такие как прямоугольная сетка улиц, застройка вдоль красных линий по образцовым проектам и др.

C XVIII века снижается стратегическое значение городов. Так, древняя крепость в самом центре города Клин, построенная в излучине реки Сестры, постепенно разрушалась, хотя в городе ещё сохранялись земляные укрепления, внутри которых находились солдатские и приказнослужительские дворы. На месте остатков крепости и окружающих её слобод был запроектирован компактный город с широкими прямыми улицами и просторными площадями.

В 1784 году для Клина был утверждён генеральный «конфирмованный» план с прямоугольной сеткой улиц (рис. 4). По регулярному плану через кремль была проложена дорога на Дмитров, были спрямлены две главные улицы старого города
- Дмитровская и Московская, они стали основой регулярного плана. На пересечении этих двух направлений запроектирована главная площадь, обстроенная по периметру купеческими лав-

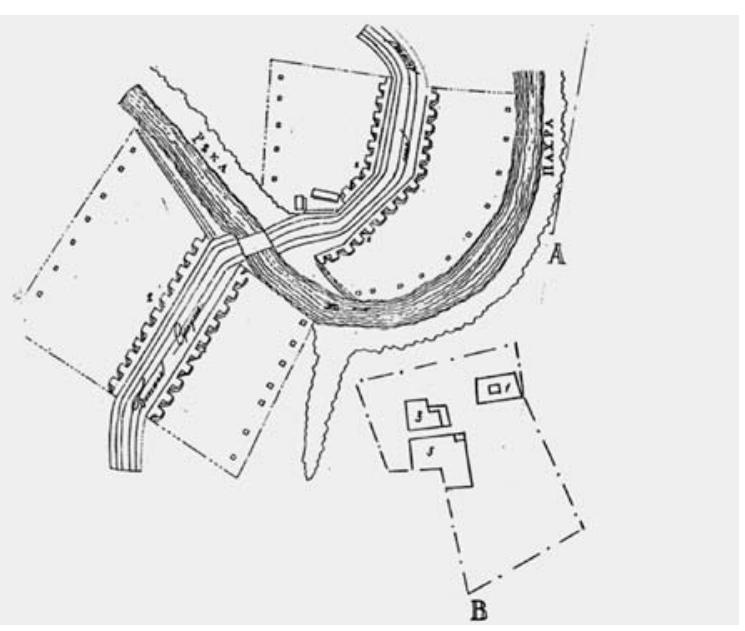

Рис. 3. План Подола.1781 год (источник: РГАДА)

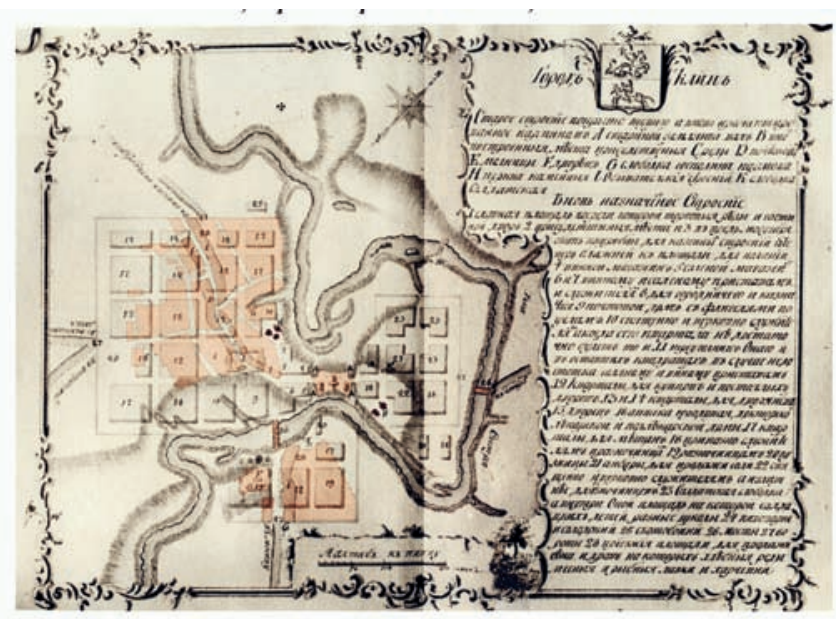

Рис. 4. Регулярный план города Клина. Вариант проектного плана. 1780-е годы (источник: «Полное собрание законов Российской Империи. Книга чертежей и рисунков. Планы городов. - СПб : Tuп. 2 Отд-ния Собств. е.и.в. канцелярии, 1839. -844 c.)

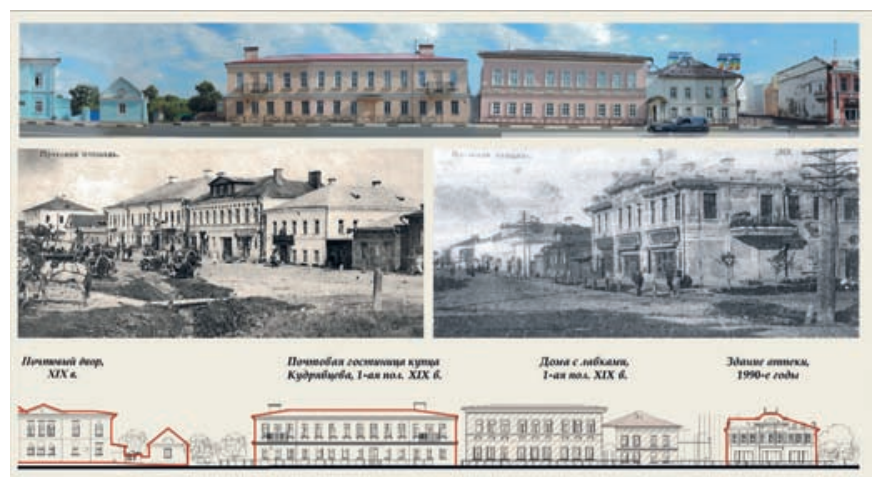

Рис. 5. Город Клин. Фрагмент застройки по образцовым проектам. Основные здания городского центра. Изображение составлено авторами с использованием архивных фотографий XIX века 
ками, магазинами и зданиями административного назначения. В центре площади разместились торговые ряды. С северной стороны площадь замыкал соборный комплекс. От площади начиналась главная улица города - Дворянская, которая проходила по территории бывшего кремля и была началом Дмитровской дороги. Вдоль главной улицы разместились основные каменные здания городского центра - присутственные места, больничный комплекс, богадельня, почтовый двор (рис. 5).

Напротив Дворянской улицы по гребню сохранившегося вала крепости проходил городской бульвар.

Согласно плану застройка должна была производиться в соответствии с социальным статусом жителей, поэтому город был разбит на кварталы: дворянские, купеческие, разночинские, церковнослужителей, мещанские, солдатские.

На въездах в город со стороны Дмитрова, Москвы, Петербурга по проекту были организованы небольшие площади с торговыми лавками, харчевнями. Большое внимание обращалось на регулирование застройки, особенно в центральной части, где для строительства казённых и жилых зданий предполагалось использование «образцовых» проектов. Дома строились в едином стиле вдоль красных линий улиц с соблюдением единой высоты, протяжённости, уровня оконных проёмов и карнизов.

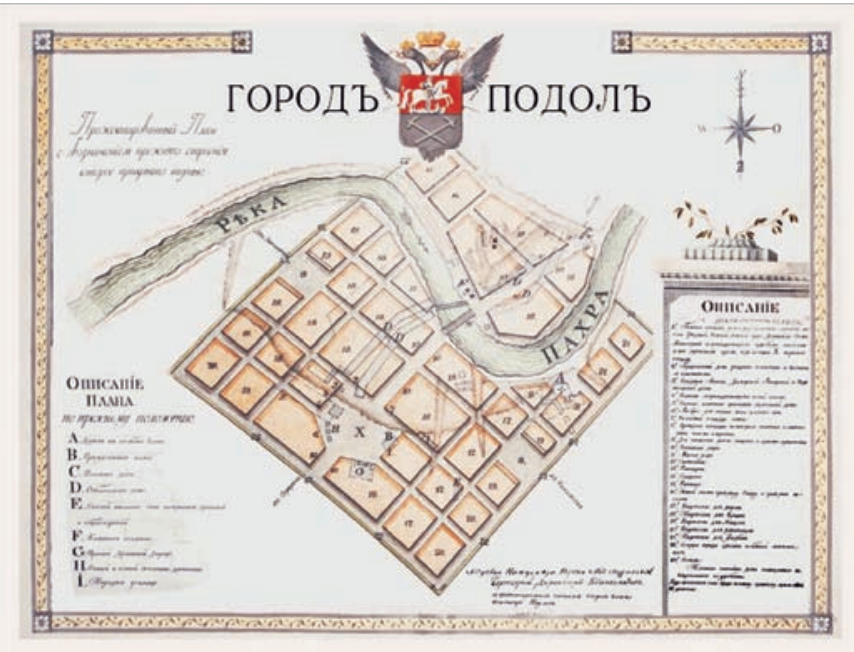

Рис. 6. Регулярный план города Подольска. 1784 год (источник: ЦГИА)

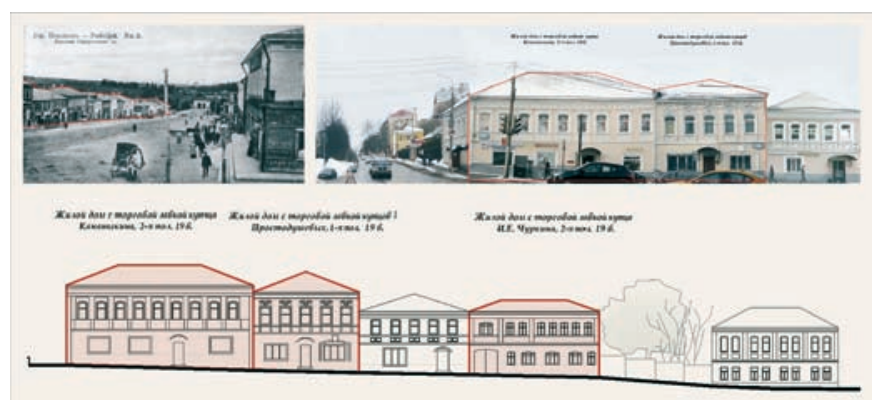

Рис. 7. Город Подольск. Фрагмент застройки «сплошною фасадою». Изображение составлено авторами с использованием архивных фотографий XIX века
Согласно принципам классицизма, зарегулированная городская среда также сопоставлялась с естественным состоянием ландшафта - с кривизной реки, крутизной склонов и оврагов, активно присутствующим в Клину. Древняя Успенская церковь, служившая ранее доминантой, оказалась в стороне от выпрямленной Дмитровской дороги и постепенно утратила свою историческую композиционную роль.

Для города Подола в 1784 году также был разработан регулярный прямоугольный план с продольно-поперечной сеткой улиц. Согласно этому плану в центре города, как и в Клину, была запроектирована главная площадь и проложены две основные улицы, чётко ориентированные по сторонам света (рис. 6). Однако сложный рельеф местности и излучина реки Пахры не позволили осуществить проект в том виде, как он был утверждён. План был доработан в 1797 году.

Помимо главной площади для присутственных мест и центральной торговой (на дороге из Серпухова в Москву) были организованы две небольшие площади на въездах из Звенигорода и бывшего города Никитска с харчевнями и торговыми лавками (аналогично плану Клина). Главной осью планировочной композиции являлась Большая Московская улица.

С середины XVIII века Серпуховская дорога была обустроена в широкий государственный почтовый тракт с высокими насыпными земляными валами по обе стороны дороги. В 1783 году был построен деревянный путевой дворец (как и в Клину), здания присутственных мест и народного училища, окончательно оформившие центральную часть города. Кварталы застраивали по единым правилам вдоль красных линий улиц, формируя классический облик центральной части уездного города [11, с. 47].

Таким образом, в Подольске сложилась система кварталов регулярной планировки вдоль главных исторических улиц, состоящая из одноэтажной и двухэтажной купеческой жилой застройки по типу «сплошною фасадою» ${ }^{1}$ и отдельных памятников архитектуры периода XVIII-XIX веков (рис. 7). Важное градостроительное значение для Подольска по сей день имеет здание присутственных мест, построенное в начале XIX века на бывшей центральной площади города и оформляющее пересечение дорог главных направлений.

Кроме того, фрагментарно сохранилась застройка вдоль бывшей Московской дороги (ныне проспект Ленина) к северу от реки Пахры. Двухэтажные каменные жилые дома с лавками внизу, живописно спускающиеся по крутому рельефу к реке, оформляли парадную главную улицу города, ведущую к центральной торговой площади. Различные по времени здания, представляют цельный, единый по масштабу и характеру фрагмент центральной застройки старого Подольска. Такие дома строились вдоль улиц «линейно» согласно утверждённому для каждого дома плану и фасаду, также по «образцовым проек-

\footnotetext{
${ }^{1}$ Термин впервые встречается в «Записи в походном журнале Петра I о закладке 16 мая 1703 г. города Санкт-Петербурга», затем широко применялся при разработке генеральных планов губернских городов XVIII века.
} 
там». В этих домах размещались не только торговые помещения и жильё владельцев, но и гостиницы и постоялые дворы.

Застройка кварталов регулярного периода вдоль главных улиц во многих исторических городах представляет собой единый градостроительный элемент, отражая характерные историко-архитектурные этапы развития города и создавая исторически однородную среду для их восприятия. Поддержание и развитие традиционных приёмов застройки и принципов исторической планировки необходимо для сохранения уникальности каждого города. Поэтому выявление кварталов исторической застройки, объектов, имеющих важное градостроительное значение, сетки улиц, линий фасадов является приоритетным при определении границ исторических поселений и составляющих их предметов охраны.

Одной из особенностей восприятия таких кварталов регулярного периода является практически фронтальный обзор с противоположной стороны улицы, позволяющий воспринимать единый масштаб сложившейся исторической застройки. Именно ленточный характер восприятия улиц, вдоль которых выстроены фасады зданий, позволяет восстановить исторические панорамы и развёртки улиц, характерные для того или иного города.

Основной проблемой визуального восприятия для данной группы памятников является то, что в больших и средних городах главные исторические улицы зачастую и сегодня служат основными транзитными транспортными артериями. Многие из них были расширены, имеют разделительные ограждения, иногда дополнены шумовыми экранами.

Эти мероприятия нарушают целостность восприятия ленты исторических улиц, вдоль которой выстроены дома «сплошною фасадою», в соответствии с первоначальным замыслом регулярного периода (рис. 8).

Третья группа: высотные доминанты. В эту группу входят церкви, храмы, монастыри, расположенные в исторической среде города.

Храмовые постройки, несмотря на разновременные периоды их строительства, составляли единую систему доминант. Такие сооружения всегда имели главенствующее градостроительное значение, часто располагались на высоком берегу реки и определяли композиционные ориентиры города.

Некоторые доминанты ставились в завершении улиц или площадей и формировали высотные акценты города. Другие, расположенные на наиболее высоких точках рельефа, служили ориентирами на важнейших сухопутных и водных направлениях. Визуальное восприятие таких доминант распространялось на значительные территории, иногда даже за пределы городской застройки. Колокольни и купола церквей виднелись с подъездных дорог, с прилегающих полей и луговых территорий, а внутри города на эти высотные постройки были ориентированы главные улицы. Кроме того, существовали визуальные связи и между самими доминантами. При этом иерархия доминант не всегда была связана со временем возникновения церковного сооружения.
Так, самым ранним архитектурным памятником города Клина является церковь Успения Пресвятой Богородицы постройки середины XVI века, которая была соборным храмом монастыря, упразднённого в 1761 году. Успенская церковь представляла собой небольшое одноглавое сооружение на четырёх столпах с угловыми арками [12, с. 233, 234].

Однако главной высотной доминантой города является церковь Воскресения Христова, расположенная в самом центре города на высоком берегу реки Сестры на месте древнего кремля. Церковь с высокой шатровой колокольней была по-
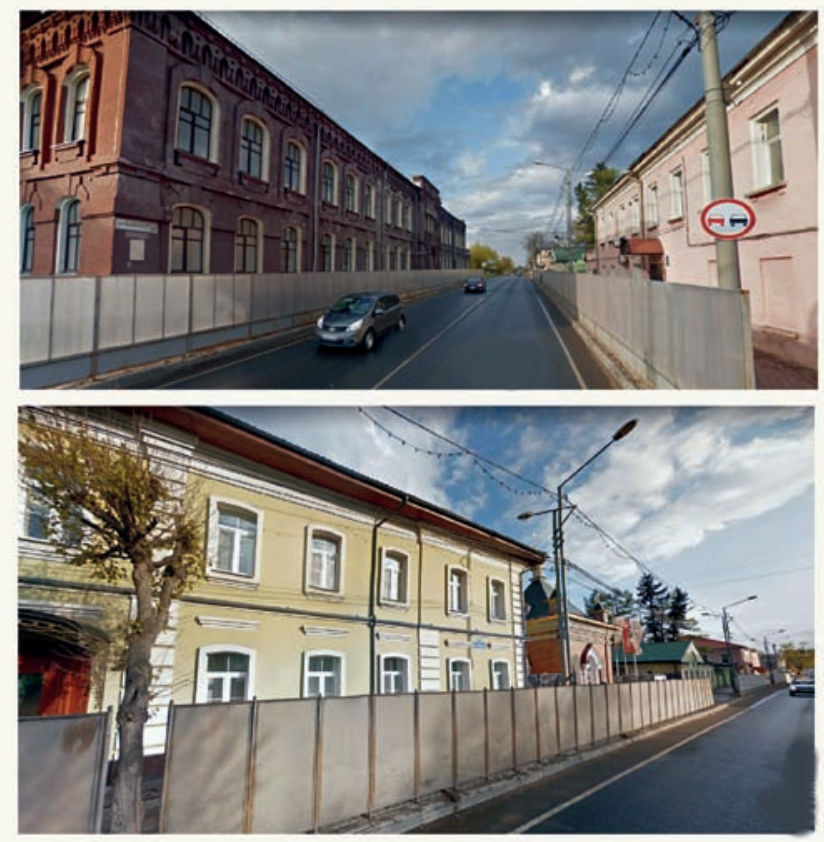

Рис. 8. Город Клин. Пример организации шумовых экранов вдоль фасадов памятников архитектуры. Фото Н.Г. Благовидовой и Е.Г. Прохорской

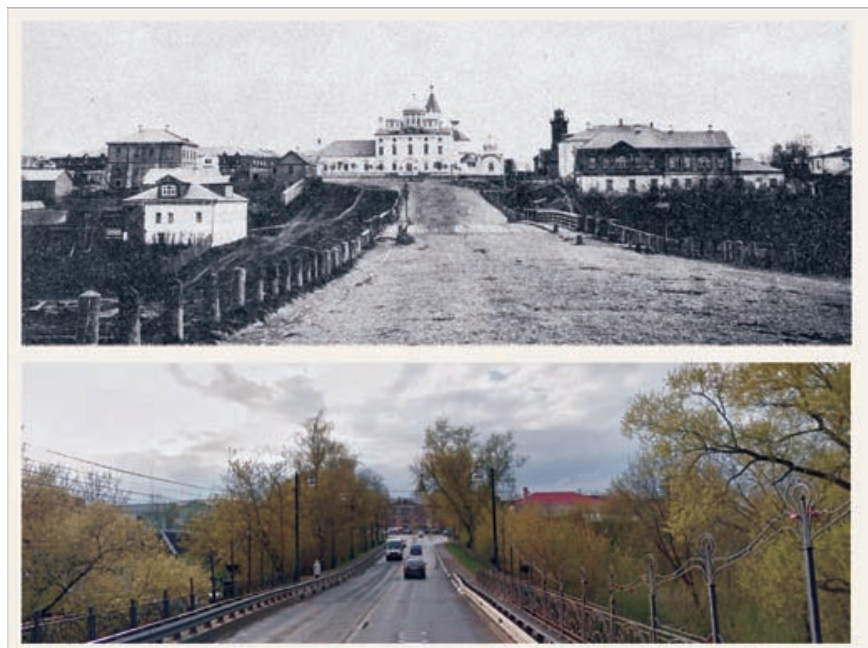

Puс. 9. Город Клин. Вид на главную доминанту города - Троицкий собор. Изображение составлено авторами с использованием архивных фото XIX века 
строена в 1712 году. Колокольня и по сей день служит самой главной вертикальной доминантой города.

В 1802-1836 годы был возведён монументальный Троицкий собор, усиливший центральную группу высотных доминант города. Его высота составляет 25 метров, собор расположен в завершении главной исторической улицы города (ныне улица Чайковского) и отражает типичные приёмы екатерининской эпохи в архитектуре (рис. 9).

В начале второй половины XIX века в композиции города появляется ещё одна высотная доминанта - церковь иконы Божией Матери «Всех Скорбящих Радость», построенная на Волоколамской дороге. Сегодня эта высотная доминанта оказалась на пересечении двух вылетных автомагистралей,

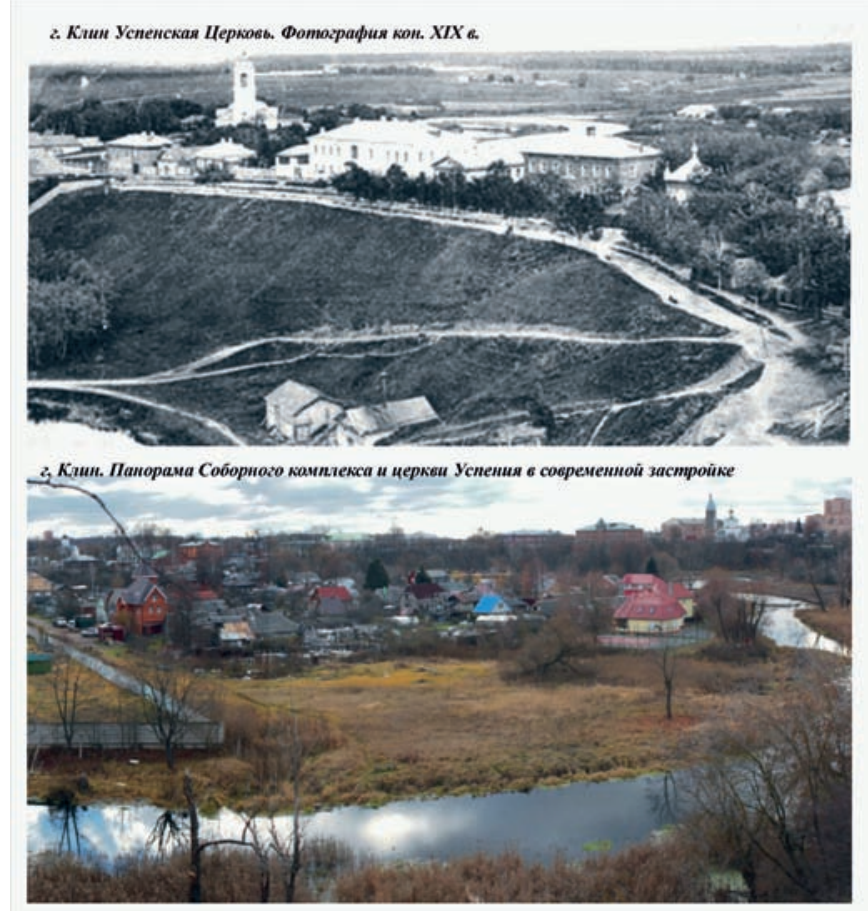

Pис. 10. Город Клин. Основные доминанты города с дальних расстояний. Изображение составлено авторами с использованием архивных фотографий XIX века

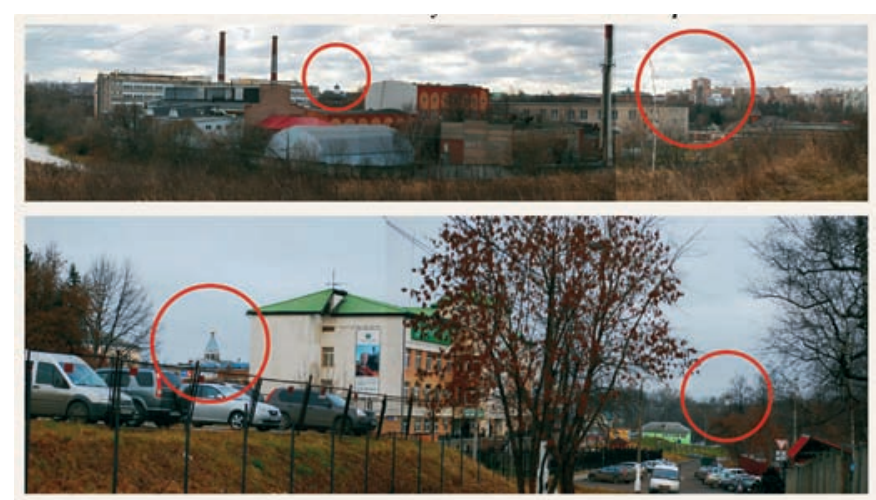

Рис. 11. Город Клин. Вид на главные соборы города в условиях сложившейся застройки. Фото Н.Г. Благовидовой и Е.Г. Прохорской что в значительной степени ухудшило её восприятие и взаимосвязи с другими высотными доминантами города. Самая поздняя постройка в городе, завершившая формирование системы высотных доминант, - церковь святителя Тихона Задонского (1864-1907).

Исторически сформировавшиеся визуальные связи между главными соборами города Клина сегодня в значительной степени нарушены преимущественно высотной жилой и общественно-деловой застройкой разных периодов. Восприятие с дальних расстояний сохранилось фрагментарно для Успенской и Воскресенской церкви с колокольней, остальные доминанты имеют раскрытие в основном с ближних расстояний (рис. 10, 11).

В Подольске также сложилась система доминант, состоявшая из церкви Воскресения Господня и Троицкого собора. Каменная церковь Воскресения Христова, возведённая на месте деревянной церкви села Подола в 1728 году, - наиболее ранняя храмовая постройка города. Невысокое здание храма поставлено на вершине крутого берега у излучины реки Пахры, что несомненно подчёркивает её доминирующее положение. Троицкий собор был возведён в 1819-1832 годы в стиле ампир. Вместе с построенными позднее торговыми рядами, раскрывавшимися полукругом в сторону главной улицы, он образовал узловой архитектурный ансамбль города.

Ведущая роль Троицкого собора в конце XX - начале XXI века была значительно подавлена жилой застройкой советского периода вдоль улицы Ленина. А визуальные связи между двумя доминантами нарушены высотным строительством в исторической части города (рис. 12).
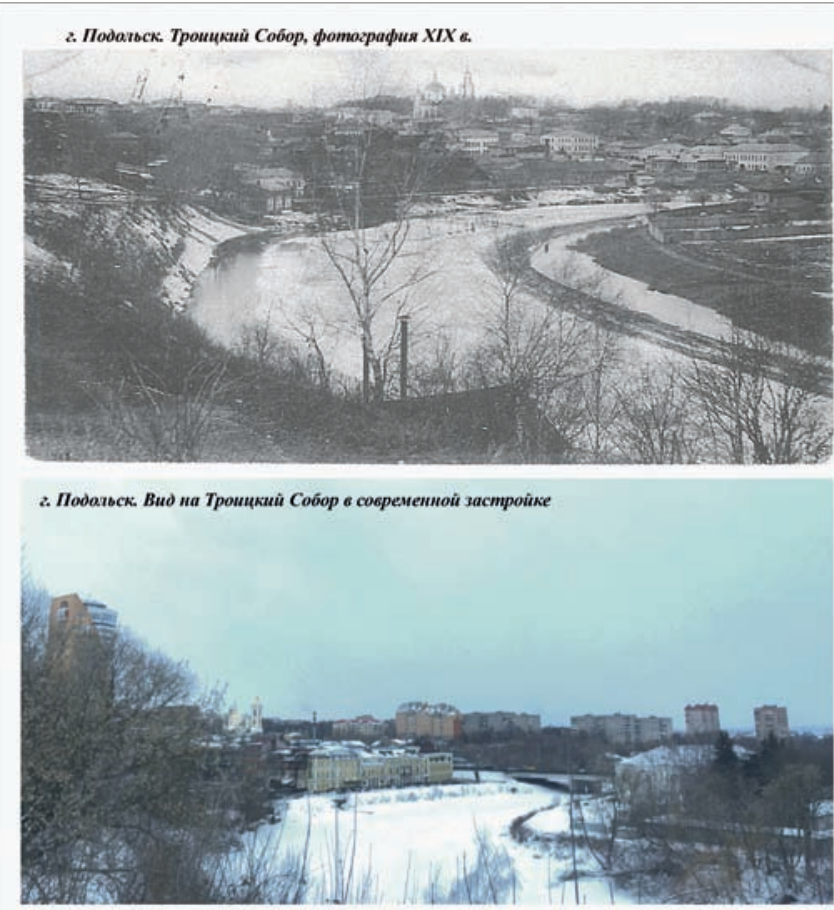

Рис. 12. Город Подольск. Вид на основную доминанту города - Троицкий собор - от церкви Воскресения Христова. Изображение составлено авторами с использованием архивных фотографий XIX века 
Таким образом, на основе проведённого анализа, можно сказать, что на восприятие системы высотных доминант в больших и средних исторических городах значительное влияние оказывает сочетание особенностей исторического природного рельефа и сложившейся планировочной структуры улиц и площадей, ориентированных на храмовые постройки. Одной из задач в отношении сохранения визуальных связей между главными акцентами города служит поддержание композиционного значения системы доминант в структуре города, исторически сложившихся видовых раскрытий, а также исключение диссонансного строительства, нарушающего обзор памятников с главных точек обзора.

Четвертая группа: усадебные комплексы XIX века.

Отдельную группу представляют архитектурно-ландшафтные комплексы, расположенные, как правило, на некотором отдалении от исторического центра, но в современных границах города (рис. 13).

Такие усадебные ансамбли характерны для XIX века - периода расцвета культурной жизни. Занимая обособленную территорию, они зачастую выполняют функции городского ландшафтного парка [13, с. 67].

Композиционная роль усадебных ансамблей тесно связана с окружающим пространством города. Визуальное восприятие комплекса усадьбы зависит от сохранности его отдельных элементов, подъездных дорог, аллей, являющихся частью архитектурно-планировочного замысла. Большое влияние на обзор памятников оказывают особенности рельефа, долины рек и бровки откосов, вдоль которых также расположены основные исторически сложившиеся зоны восприятия и видовые точки.

В черте современного города Клина находятся три усадьбы, каждая из которых связана с именем великого композитора Петра Ильича Чайковского: усадьба, где жил композитор; усадьба Демьяново; усадьба Майданово.

Одна из главных исторических улиц, ведущая к центру города, носит имя П.И. Чайковского. Вдоль неё фрагментарно сохранилась историческая одноэтажная и двухэтажная купеческая застройка XVIII-XIX веков. Сохранение исторического облика улицы имеет большое градостроительное значение для объединения исторических территорий: центрального ядра - собора Воскресения Христова, главной доминанты города - и ландшафтной территории усадьбы П.И. Чайковского. Восприятие главной доминанты в створе этой улицы распространяется на значительное расстояние и носит динамический характер при движении к центру (рис. 14).

Исторические планировочные связи с усадьбами Демьяново и Майданово в Клину сформированы вдоль основной природной оси - русла реки Сестры. Основные зоны восприятия архитектурно-ландшафтных памятников расположены вдоль берегов реки, а композиция усадеб носит обособленный характер и практически не связана с остальными зонами концентрации объектов культурного наследия в центральной части города.
В городе Подольске сформировалась схожая ситуация по пространственной организации усадебных комплексов. Все они словно нанизаны на природно-ландшафтную ось реку Пахру. К исторической части города в излучине реки примыкает территория музея-заповедника «Подолье».

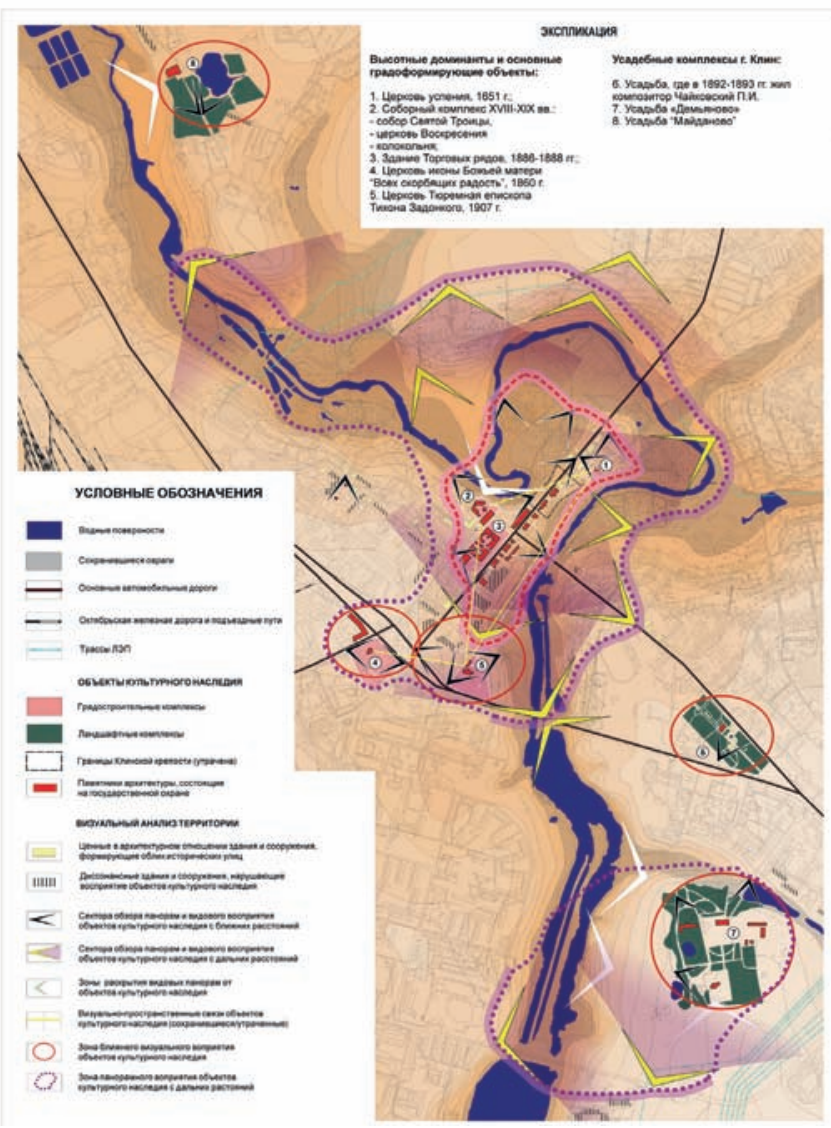

Рис. 13. Город Клин. Фрагмент схемы визуального восприятия объектов культурного наследия. Схема составлена Е.Г. Прохорской
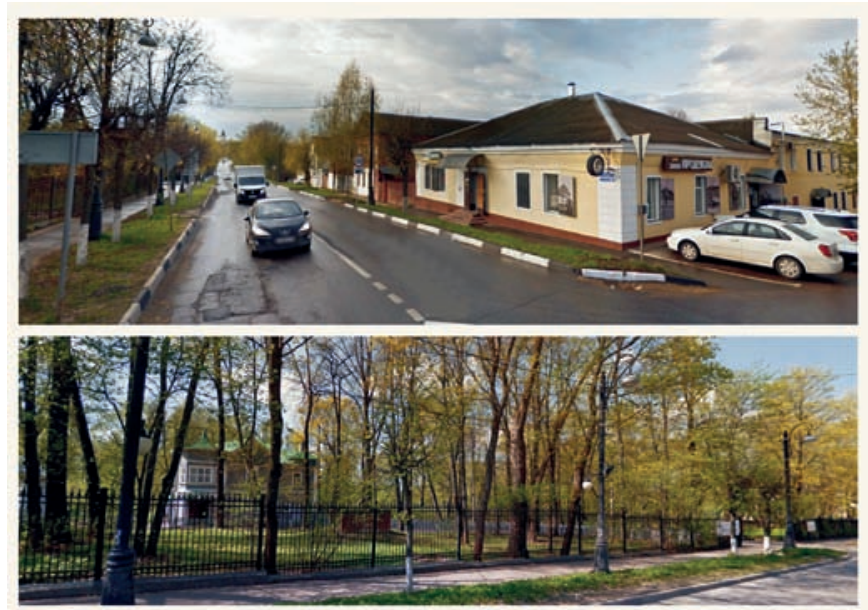

Рис. 14. Город Клин. Вид на Троицкий собор от усадьбы П.И. Чайковского в створе улицы Чайковского. Фото Н.Г. Благовидовой и Е.Г. Прохорской 
Территория музея расположена на пологом склоне левого берега реки Пахры, от высокого плато рельеф оврагами спускается к реке. Овраг ранее служил естественной границей города на севере. Эта территория имеет важное градостроительное значение в структуре города, позволяя сохранить
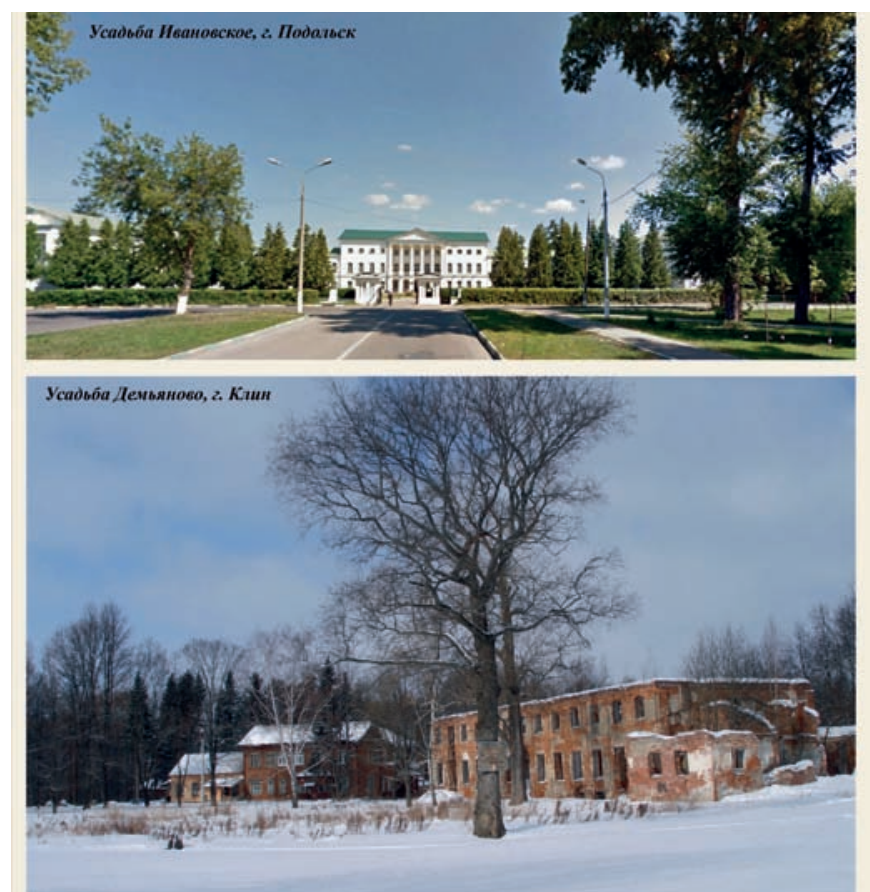

Рис. 15. Архитектурно-ландшафтные комплексы усадеб «Ивановское» (город Подольск) и «Демьяново» (город Клин). Фото Н.Г. Благовидовой и Е.Г. Прохорской

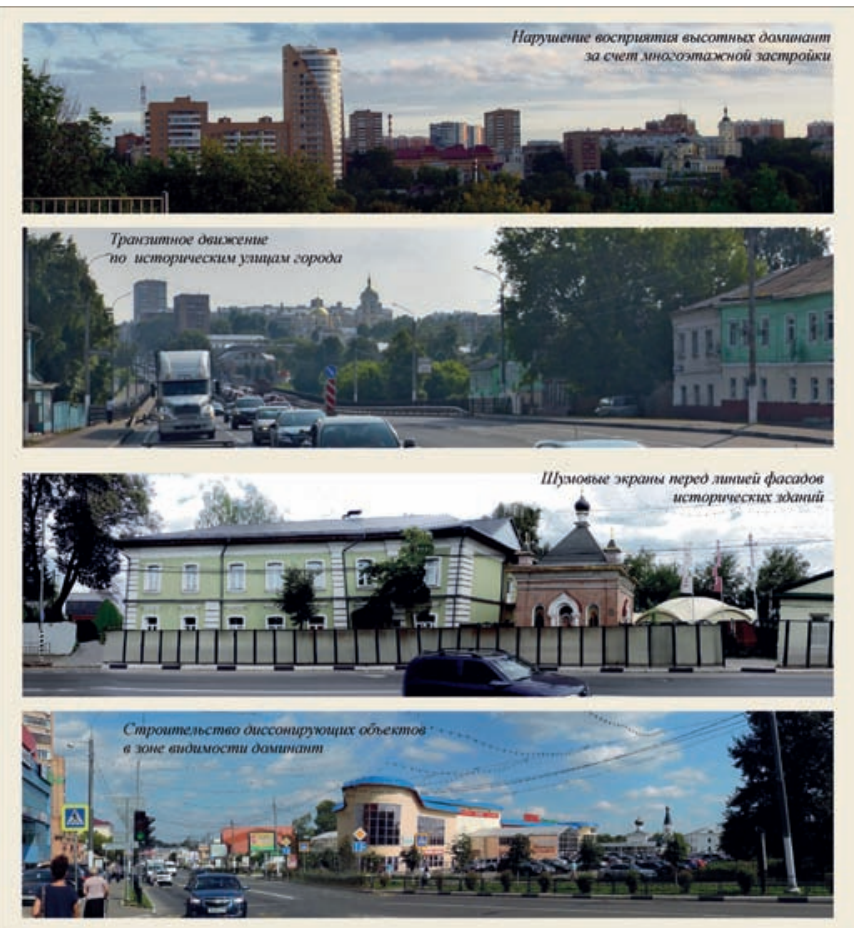

Рис. 16. Примеры нарушения композиционной роли основных градоформирующих объектов. Фото Н.Г. Благовидовой и Е.Г. Прохорской естественный исторический ландшафт вдоль русла реки и сложившиеся раскрытия и панорамы восприятия главных высотных доминант города.

Архитектурно-ландшафтные комплексы, вошедшие в черту города Подольска в XX веке, также расположены на берегу реки Пахры поодаль от исторической части - это усадьба Ивановское и усадьба Фон-Мекк в Плещеево (рис. 15). Основные точки обзора усадьбы расположены вдоль берега реки Пахры, а также с подъездных дорог и аллей. В последние годы панорамы с дальних расстояний были нарушены новой многоэтажной застройкой.

Таким образом, для данной группы объектов культурного наследия большое значение имеет сохранение зон восприятия ландшафтно-усадебных комплексов вдоль естественных природных рубежей, а также видовых точек вдоль подъездных аллей, являющихся неотъемлемой особенностью архитектурного памятника.

Этап на рубеже XVIII-XIX веков является переломным в развитии больших и средних городов. Строительство железной дороги дало предпосылки для развития промышленности, что в значительной степени отразилось на планировке городов, оставив также памятники промышленной архитектуры (комплекс стекольного завода в Клину, завод компании «Зингер» в Подольске). В годы после Великой Отечественной войны началось массовое жилищное строительство, далеко не всегда вписывающееся в сложившийся исторический масштаб застройки.

Развитие промышленных территорий и массовое жилищное строительство в значительной степени повлияли на визуальное восприятие исторической целостности больших и средних городов. В большинстве случаев это влияние носило диссонансный характер, нарушая масштаб исторической застройки и искажая фон восприятия памятников в сложившейся историко-градостроительной среде. В начале XIX века ситуация усугубилась строительством в исторических границах городов современной многоэтажной застройки и зданий общественно-делового и торгового назначения. Такое строительство без учёта масштаба и характера исторической застройки постепенно привело к снижению композиционной роли основных градоформирующих объектов и высотных доминант (рис. 16).

В результате анализа рассмотренных выше групп объектов культурного наследия были выделены следующие особенности пространственной организации исторических городов в современных условиях развития. Они представляют собой совокупность природного ландшафта, рядовой застройки на основе регулярной планировки, системы высотных доминант и пространственных акцентов:

- наличие композиционно-градостроительных акцентов в исторически сформировавшемся ядре, восприятие которых зависит от сохранности их доминирующей роли в структуре города и природных особенностей;

- компактность фрагментарно сохранившихся кварталов регулярного периода, позволяющая обеспечить фронталь- 
ное восприятие отдельных объектов культурного наследия с ближних расстояний;

- ленточный характер исторической застройки вдоль основных направлений ядра города, формирующий основные панорамы улиц;

- композиционные связи между системой высотных доминант города;

- архитектурно-ландшафтные комплексы, выстроенные вдоль основных природных осей, воспринимаемые с дальних расстояний и имеющие систему видовых точек, которые играют важную роль в общей композиции города.

В результате проведённого анализа было показано, что сложившаяся градостроительная ситуация оказывает влияние на условия целостного визуального восприятия объектов культурного наследия в исторической среде.

\section{$* * *$}

Главными проблемами в отношении восприятия объектов культурного наследия в городах Московской области продолжают оставаться следующие:

- нарушение условий восприятия высотных доминант с главных видовых точек, особенно с дальних расстояний, в связи со строительством в историческом центре высотных зданий, не отвечающих по масштабу и характеру сложившейся застройки;

- нарушение визуальных связей между основными градоформирующими объектами в историческом центре города изза наличия диссонирующих объектов (современных торговых центров, надстройки исторических зданий и пр.);

- нарушение восприятия рядовой застройки вдоль основных исторических улиц, по которым проходят транзитные потоки автотранспорта через исторический центр;

- снижение композиционной роли усадебных комплексов, оказавшихся в окружении нового строительства, нарушение видовых точек с исторических подъездных аллей.

Для сохранения целостности исторического облика города необходим комплексный подход к решению вопросов восприятия памятников архитектуры в градостроительной среде. 0дной из важнейших составляющих такого подхода является проведение детального анализа визуального восприятия объектов культурного наследия в сложившейся градостроительной среде на основе исторических планов и фотографий.

Определение зон восприятия с ближних и дальних расстояний, панорамных раскрытий, главных видовых точек и визуальных связей позволяет выявить комплекс мероприятий для определения границ исторического поселения, режимов использования его территорий и приоритеты дальнейшего развития города в современных условиях, что даёт возможность сохранить композиционное значение основных объектов культурного наследия в исторической среде города.

\section{Лuтература}

1. Выборный, В.Н. Этика воссоздания «памятников» архитектуры / В.Н. Выборный // Проблемы воссоздания утраченных памятников архитектуры. - М. : Жираф, 1998. - 117 с.

2. Михалчева, С.Г. Градостроительный и ландшафтно-визуальный анализ : учеб. пособие по направлению подготовки 07.03 .04 «Градостроительство» / С.Г. Михалчева - Пенза : ПГУАС, 2016. - 120 с.

3. Panonopm, В.Л. Стоянки, городища, курганы / В.Л. Рапопорт // Красногорье. Историко-краеведческий альманах. - 1997. - № 1. - С. 14-18.

4. Лени, А.А. Внешние факторы, ограничивающие развитие исторических поселений Московской области [Электронный ресурс] / А.А. Ленц // Architecture and Modern Information Technologies. - 2019. - № 4 (49). - С. 201-214. - Режим доступа: https://marhi.ru/AMIT/2019/4kvart19/PDF/13_lenz. pdf (дата обращения 29.04.2021). DOI: 10.24411/1998-48392019-00014.

5. Благовидова, Н.Г. Кластерный метод формирования устойчивых исторических поселений [Электронный ресурс] / Н.Г. Благовидова, Н.В. Юдина // Architecture and Modern Information Technologies. - 2019. - № 4 (49). - C. 183-200. - Режим доступа: https://marhi.ru/АMIT/2019/4kvart19/ PDF/12_blagovidova.pdf (дата обращения 02.05.2021). DOI: 10.24411/1998-4839-2019-00013.

6. Гандельсман, Б.В. Современные методы сохранения и реконструкции исторических центров средних и больших городов Скандинавии [Электронный ресурс] / Б.В. Гандельсман, А.Н. Милашевская // Architecture and Modern Information Technologies. - 2020. - № 4 (53). - С. 300-322. - Режим доступа: https://marhi.ru/АMIT/2020/4kvart20/ PDF/18_gandelsman.pdf (дата обращения 12.05.2021). DOI: 10.24411/1998-4839-2020-15318.

7. Регамэ, С.К. Сочетание новой и сложившейся застройки при реконструкции городов / С.К. Регамэ, Д.В. Брунс, Г.Б. Омельяненко. - М. : Стройиздат, 1989. - 143 с.

8. Поспелов, Е.М. Топономический словарь Московской области. Селения и реки Подмосковья / Е.М. Поспелов. -М. : Профиздат, 2000. - 315 с.

9. Юдин, В.С. Край наш Клинский / В.С. Юдин. - Клин, 1999. - 215 c.

10. Рубцов, Д.А. Клинский уезд по документам XV-XVIII веков: исторические материалы для составления приходских летописей / Д.А. Рубцов. - Клин, 2009. - 78 с.

11. Памятники архитектуры Московской области : иллюстрированный научный каталог. Т. 2 / под общ. ред. Е.Н. Подъяпольской // Ком. по культуре Администрации Моск. обл. - М. : Стройиздат, 1975. - 244 С.

12. Ильин, М.A. Подмосковье : Книга-спутник по древним подмосковным городам, сёлам и старым усадьбам (XIV-XIX вв.) / М.А. Ильин; изд. третье. - М. : Искусство, 1974. - 315 с.

13. Полякова, Г.А. Проблемы охраны старинных усадеб как элементов исторического природного наследия / Г.А. 
Полякова, А.Н. Швецов // Материалы Четвертой научнопрактической конференции «Экологические проблемы сохранения исторического и культурного наследия». Бородино, 17-18 ноября 1999 г. - М. : Российский науч.исслед. ин-т культурного и природного наследия 2000. - С. 62-68.

\section{References}

1. Vybornyi V.N. Etika vossozdaniya "pamyatnikov» arkhitektury [Ethics of reconstruction of "monuments" of architecture]. In: Problemy vossozdaniya utrachennykh pamyatnikov arkhitektury [Problems of reconstruction of lost monuments of architecture]. Moscow, Zhiraf Publ., 1998, 117 p. (In Russ.)

2. Mikhalcheva S.G. Gradostroitel'nyi i landshaftno-vizual'nyi analiz : ucheb. posobie po napravleniyu podgotovki 07.03.04 «Gradostroitel'stvo» [Urban planning and landscape-visual analysis: textbook. Manual in the direction of training 07.03.04 "Urban planning"]. Penza, PGUAS Publ., 2016, 120 p. (In Russ.)

3. Rapoport V.L. Stoyanki, gorodishcha, kurgany [Parkinglots, settlements, barrows]. In: Krasnogor'e. Istoriko-kraevedcheskii al'manakh [Krasnogorie. Historical and Local Lore Almanac], 1997, no. 1, pp. 14-18. (In Russ.)

4. Lents A.A. Vneshnie faktory, ogranichivayushchie razvitie istoricheskikh poselenii Moskovskoi oblasti [External factorslimiting the development of historical settlements in the Moscow region]. In: Architecture and Modern Information Technologies, 2019, no. 4 (49), pp. 201-214. Access mode: https://marhi.ru/AMIT/2019/4kvart19/PDF/13_lenz.pdf (accessed 29.04.2021). DOI: 10.24411/1998-4839-2019-00014. (In Russ., abstr.in Engl.)

5. Blagovidova, N.G., Yudina N.V. Klasternyi metod formirovaniya ustoichivykh istoricheskikh poselenii [Cluster method of forming sustainable historical settlements]. In: Architecture and Modern Information Technologies, 2019, no. 4 (49), pp. 183-200. Access mode: https://marhi.ru/AMIT/2019/4kvart19/PDF/12 blagovidova.pdf (accessed: 02.05.2021). DOI: 10.24411/1998-48392019-00013. (In Russ., abstr.in Engl.)

6. Gandel'sman B.V., Milashevskaya A.N. Sovremennye metody sokhraneniya i rekonstruktsii istoricheskikh tsentrov srednikh i bol'shikh gorodov Skandinavii [Modern methods of preservation and reconstruction of historical centers of medium andlarge cities in Scandinavia]. In: Architecture and Modern Information Technologies, 2020, no. 4 (53), pp. 300-322. Access mode: https://marhi.ru/AMIT/2020/4kvart20/PDF/18_ gandelsman.pdf (accessed 12.05.2021). DOI: 10.24411/19984839-2020-15318. (In Russ., abstr.in Engl.)

7. Regame S.K. Bruns D.V., Omel'yanenko G.B. Sochetanie novoi i slozhivsheisya zastroiki pri rekonstruktsii gorodov [Combination of new and existing buildings during the reconstruction of cities]. Moscow, Stroiizdat Publ., 1989, 143 p. (In Russ.)

8. Pospelov E.M. Toponomicheskii slovar' Moskovskoi oblasti. Seleniya i reki Podmoskov'ya [Toponomical Dictionary of the Moscow Region. Settlements and rivers of the Moscow region]. Moscow, Profizdat Publ., 2000, 315 p. (In Russ.)

9. Yudin V.S. Krai nash Klinskii [Our Land Klinsky]. Klin, 1999, 215 p.

10. Rubtsov D.A. Klinskii uezd po dokumentam XV-XVIII vekov: istoricheskie materialy dlya sostavleniya prikhodskikh letopisei [Klinsky uyezd according to documents of the 15th - 18th centuries: historical materials for compiling parish chronicles]. Klin, 2009, 78 p. (In Russ.)

11. Pod"yapol'skaya E.N. (total. ed.). Pamyatniki arkhitektury Moskovskoi oblasti : illyustrirovannyi nauchnyi katalog [Architectural monuments of the Moscow region: illustrated scientific catalog], Vol. 2. Moscow, Stroiizdat Publ., 1975, 244 p. (In Russ.)

12. Il'in M.A. Podmoskov'e : Kniga-sputnik po drevnim podmoskovnym gorodam, selam i starym usad'bam (XIV-XIX Vv.) [Moscow suburbs: A companion book on the ancient towns, villages and old estates near Moscow (XIV - XIX centuries)], third edition. Moscow, Iskusstvo Publ., 1974, 315 p. (In Russ.)

13. Polyakova G.A., Shvetsov A.N. Problemy okhrany starinnykh usadeb kak elementov istoricheskogo prirodnogo naslediya [Problems of protection of old estates as elements of historical natural heritage]. In: Materialy Chetvertoi nauchnoprakticheskoi konferentsii «Ekologicheskie problemy sokhraneniya istoricheskogo i kul'turnogo naslediya» [Materials of the Fourth Scientific and Practical Conference "Environmental Problems of Preservation of Historical and Cultural Heritage"], Borodino, November 17-18, 1999. Moscow, Russian Research Institute of Cultural and Natural Heritage Publ.,2000, pp. 62-68. (In Russ.) 